\title{
Retraction
}

\section{Retracted: Mechanism of Hepatoprotective Effect of Boesenbergia rotunda in Thioacetamide-Induced Liver Damage in Rats}

\author{
Evidence-Based Complementary and Alternative Medicine
}

Received 28 May 2018; Accepted 28 May 2018; Published 18 July 2018

Copyright (C) 2018 Evidence-Based Complementary and Alternative Medicine. This is an open access article distributed under the Creative Commons Attribution License, which permits unrestricted use, distribution, and reproduction in any medium, provided the original work is properly cited.

Evidence-Based Complementary and Alternative Medicine has retracted the article titled "Mechanism of Hepatoprotective Effect of Boesenbergia rotunda in Thioacetamide-Induced Liver Damage in Rats" [1]. Figure 5(a)-(iv) is reused from Figure 15A-II in an article by the same authors, Salama et al. [2].

An institutional investigation by the University of Malaya found there was no system to index and file data and images to avoid mislabeling and mishandling, which led to errors and duplication of research data. The authors did not thoroughly check the manuscript before submission.

The authors said that to save time, animal experiments were conducted on both plants at the same time and to cut costs, immunohistochemistry staining was performed at the same time on the liver tissues collected from all animals of both experiments using one kit and one protocol. In addition, the results of both experiments were very close and so they mixed up images between the two experiments.

\section{References}

[1] S. M. Salama, M. A. Abdulla, A. S. Alrashdi, and A. H. A. Hadi, "Mechanism of hepatoprotective effect of Boesenbergia rotunda in thioacetamide-induced liver damage in rats," Evidence-Based Complementary and Alternative Medicine, vol. 2013, Article ID 157456, 13 pages, 2013.

[2] S. M. Salama, M. A. Abdulla, A. S. AlRashdi, S. Ismail, S. S. Alkiyumi, and S. Golbabapour, "Hepatoprotective effect of ethanolic extract of Curcuma longa on thioacetamide induced liver cirrhosis in rats," BMC Complementary and Alternative Medicine, vol. 13, article no. 56, 2013. 


\title{
Mechanism of Hepatoprotective Effect of Boesenbergia rotunda
} in Thioacetamide-Induced Liver Damage in Rats

\author{
Suzy M. Salama, ${ }^{1}$ Mahmood A. Abdulla, ${ }^{1}$ Ahmed S. AlRashdi, ${ }^{1}$ and A. Hamid A. Hadi ${ }^{2}$ \\ ${ }^{1}$ Department of Biomedical Science, Faculty of Medicine, University of Malaya, 50603 Kuala Lumpur, Malaysia \\ ${ }^{2}$ Department of Chemistry, Faculty of Science, University of Malaya, 50603 Kuala Lumpur, Malaysia
}

Correspondence should be addressed to Mahmood A. Abdulla; mahmood955@yahoo.com

Received 23 March 2013; Revised 2 June 2013; Accepted 17 June 2013

Academic Editor: Sedigheh Asgary

Copyright (C 2013 Suzy M. Salama et al. This is an open access article distributed under the Creative Commons Attribution License, which permits unrestricted use, distribution, and reproduction in any medium, provided the original work is properly cited.

Background. Researchers focused on developing traditional therapies as pharmacological medicines to treat liver cirrhosis. Objectives. Evaluating the hepatoprotective activity of Boesenbergia rotunda (BR) rhizome ethanolic extract on thioacetamideinduced liver cirrhosis in rats. Methods. Male Sprague-Dawley rats were intraperitoneally injected with $200 \mathrm{mg} / \mathrm{kg}$ TAA 3 times/week and daily oral administration of $250 \mathrm{mg} / \mathrm{kg}, 500 \mathrm{mg} / \mathrm{kg}$ of BR extract, and $50 \mathrm{mg} / \mathrm{kg}$ of the reference drug Silymarin for 8 weeks. At the end of the experiment, Masson's trichrome staining was used to measure the degree of liver fibrosis. Hepatic antioxidant enzymes (CAT and GPx), nitrotyrosine, cytochrome (P450 2E1), matrix metalloproteinase (MMP-2 and MMP-9), tissue inhibitor of metalloproteinase (TIMP-1), and urinary 8-hydroxyguanosine were measured. Serum levels of transforming growth factor TGF- $\beta 1$, nuclear transcription factor NF- $\kappa$ B, proinflammatory cytokine IL-6, and caspase-3 were evaluated. Serum protein expression and immunohistochemistry of proapoptotic Bax and antiapoptotic Bcl-2 proteins were measured and confirmed by immunohistochemistry of Bax, Bcl-2, and proliferating cell nuclear antigen (PCNA). Results. BR treatment improved liver histopathology, immunohistochemistry, and biochemistry, triggered apoptosis, and inhibited cytokines, extracellular matrix proteins, and hepatocytes proliferation. Conclusion. Liver cirrhosis progression can be inhibited by the antioxidant and antiinflammatory activities of BR ethanolic extract while preserving the normal liver status.

\section{Introduction}

Pharmaceutical drugs that depend on compounds such as colchicine and interferons are currently available for the treatment of liver cirrhosis but with either unreliable efficacies or high situations of side effects [1]. A number of natural compounds produced from vegetation offer alternative healthcare options that are more effective and safe [2]. Ingredients from recently found or already known plant varieties are regularly being examined on experimental animals [3]. The prospective tasks and efficiency of plant extracts in liver diseases are yet to be analyzed. The ethanolic extract of Curcuma longa rhizomes extract was recently proved to exhibit hepatoprotective efficacy against TAA intoxication in rats [4]. A large number of medicinal plants with hepatoprotective activity have been reported by several researchers $[5,6]$. Boesenbergia rotunda (BR) rhizomes is one that is awaiting more analysis of its part in the pathology of the liver.
Boesenbergia rotunda is one of the species that belongs to family Zingiberaceae and is traditionally used in folk medicine in Southeast Asia and commonly known as temu kunci. Medical research in the past used different solvents in preparing extracts from BR such as methanol, chloroform, and hexane. The methanol extract of BR was found to contain Quercetin and Kaempferol, which are well-known antioxidant and anti-inflammatory [7]. Chloroform or hexane extract of BR was found to contain other important flavanones and chalcones which are highly antioxidant compounds [8]. Furthermore, previous studies have revealed various bioactivities of $\mathrm{BR}$ rhizome extract such as anticancer [9], antibacterial [10], wound healing activity [11], and antiulcerogenic [12]. Our previous study examined the effectiveness of the ethanol-based extract of BR as a preventive therapy on a rat model of liver cirrhosis induced by thioacetamide, and our results revealed that BR extract exhibited significant hepatoprotective activity [13]. As an extension of our initiatives, in 
TABLE 1: Experimental design.

\begin{tabular}{|c|c|c|c|c|}
\hline Group & $\begin{array}{l}\text { Number } \\
\text { of } \\
\text { animals }\end{array}$ & $\begin{array}{l}\text { Intraperitoneal } \\
\text { injection (three } \\
\text { times/week) }\end{array}$ & $\begin{array}{c}\text { Oral } \\
\text { administration } \\
(5 \mathrm{~mL} / \mathrm{kg})\end{array}$ & $\begin{array}{c}\text { Durations } \\
\text { (weeks) }\end{array}$ \\
\hline $\begin{array}{l}\text { Normal } \\
\text { control }\end{array}$ & 6 & $\begin{array}{l}\text { Sterile distilled } \\
\text { water }(1 \mathrm{~mL} / \mathrm{kg})\end{array}$ & $10 \%$ Tween-20 & 8 \\
\hline $\begin{array}{l}\text { Cirrhosis } \\
\text { control }\end{array}$ & 6 & TAA & $10 \%$ Tween-20 & 8 \\
\hline $\begin{array}{l}\text { Reference } \\
\text { control }\end{array}$ & 6 & TAA & $\begin{array}{l}\text { Silymarin } \\
50 \mathrm{mg} / \mathrm{kg}\end{array}$ & 8 \\
\hline $\begin{array}{l}\text { Low dose } \\
\text { B. rotunda }\end{array}$ & 6 & TAA & $\begin{array}{l}\text { B. rotunda } \\
250 \mathrm{mg} / \mathrm{Kg}\end{array}$ & 8 \\
\hline $\begin{array}{l}\text { High dose } \\
\text { B. rotunda }\end{array}$ & 6 & TAA & $\begin{array}{l}\text { B. rotunda } \\
500 \mathrm{mg} / \mathrm{kg}\end{array}$ & 8 \\
\hline
\end{tabular}

this study, we studied the mechanism of the protective effect of BR ethanol extract in TAA intoxication. Silymarin was also used in our study as a well-known hepatoprotectant reference drug extracted from the seeds of Silybum marinum plant [14].

\section{Materials and Methods}

2.1. Animals. Thirty male Sprague-Dawley rats $(180-250 \mathrm{~g})$ were used in the study. The rats were held in cages with wire bottoms at $25 \pm 2^{\circ} \mathrm{C}$, given tap water and conventional pellet, and revealed to a 12 hours of light-dark cycle at 50 $60 \%$ moisture in well-prepared animal house. Throughout the test, all animals obtained individual proper care according to the requirements defined in the "Guide for the Care and Use of Laboratory Animals" readified by the Nationwide Academia of Sciences and released by the National Institution of Health. The research was accepted by the Committee Panel for Animal Analysis, Faculty of Medicine, University of Malaya, Malaysia PM/28/08/2009/MAA.

2.2. Experiment. Animal groups were divided into 5 categories of 6 rats each (Table 1). TAA was ready by complete dissolving of TAA crystals (Sigma-Aldrich, USA) in sterile distilled water [15]. Silymarin (International Clinical, USA) was used as a reference drug and prepared by complete dissolving in $10 \%$ Tween- 20 .

At the end of the experimental period, the rats were sacrificed, and blood was collected as mentioned in our previous work [13]. Liver tissues were excised, cleaned with ice-cold normal saline, and blotted, and some tissues were prepared for histopathology and immunohistochemistry evaluation. Some other liver tissues were washed in $0.02 \mathrm{~mol} / \mathrm{L} \mathrm{PBS}(\mathrm{pH}$ 7.0-7.2) to get rid of excess blood. One gram of each liver was sampled and homogenized $(10 \% \mathrm{w} / \mathrm{v})$ in $50 \mathrm{mM}$ cold potassium phosphate buffer ( $\mathrm{pH}$ 7.4) by using teflon homogenizer (Polytron, Heidolph RZR 1, Germany). The resulting tissue homogenate was allowed to centrifuge at $3500 \mathrm{rpm}$ for 10 minutes at $4^{\circ} \mathrm{C}$ in a centrifuge (Heraeus, Germany). The collected supernatant was divided into aliquots and then kept at $-80^{\circ} \mathrm{C}$ till being assayed. The protein content in the liver tissue homogenate collected from all animals was assayed by using bovine serum albumen (BSA) according to Lowry method [16]. Blood samples were collected from all rats into carefully labeled tubes containing activated gel and allowed to clot and centrifuge at $3000 \mathrm{rpm}$ for $10 \mathrm{~min}$ at $4^{\circ} \mathrm{C}$. The collected serum samples were divided into aliquots and then kept at $-80^{\circ} \mathrm{C}$. Clean urine samples from all animals were collected 24 hours before sacrifice and kept at $-80^{\circ} \mathrm{C}$ before assaying for levels of 8-hydroxy-deoxyguanosine.

2.3. Liver Tissue Content of CYP2E1. The cytochrome enzyme (CYP2E1) plays a crucial role in the metabolism of TAA in the liver microsome [17]. Aliquots of the tissue homogenate from all rats were tested for the level of CYP2E1 enzyme using microtiter plate precoated with monoclonal antibody specific to rat CYP2E1 and following the instructions of Uscn Life Science sandwich enzyme immunoassay (E90988Ra, China).

2.4. Evaluation of Urine 8-OH-dG and Hepatic Nitrotyrosine. The free radicals generated from biotransformation of TAA in the liver result in oxidative damage via their covalent binding to the macromolecules of hepatocytes including DNA, protein, and lipid molecules causing necrosis of hepatocytes [18]. In our previous study, the level of malondialdehyde has been evaluated in the liver tissue homogenate [13]. In this study, the hepatic level of nitrotyrosine was measured as a marker for protein oxidation [19] utilizing a multiclonal antinitrotyrosine antibody and nitrotyrosine-horseradish conjugate as per the company's manuals (MyBiosource MBS722419, USA). Urine level of 8-hydroxy-deoxyguanosine (8-OH-dG) was evaluated as a marker for DNA oxidation [20] using monoclonal antibody specific to $8-\mathrm{OH}-\mathrm{dG}$ and following the kit instructions (Genox KOG-HS10E, USA). The principle of the assay is based on a competitive enzyme-linked immunoabsorbent method for measuring the quantity of 8 -hydroxy-2 $2^{\prime}$-deoxyguanosine adduct resulting from DNA oxidation.

2.5. Evaluation of Antioxidant Enzymes (CAT and GPx). Endogenous antioxidants, SOD, CAT, and GPx signify the first array of protection against the harms of free radicals and are essential for avoiding or at least reducing the occurrence and development of diseases [21]. In our previous experiment, we evaluated the level of superoxide dismutase (SOD) in the liver tissue homogenate of rats. In this study, the levels of catalase (CAT) and glutathione peroxidase (GPx) enzymes were assayed in the liver tissue homogenate collected from all animals following the instructions of Cayman kits (Sigma Cat no. 707002 and no. 703102, resp.). In brief, CAT activity was evaluated by Purpald Chromagen measuring the formaldehyde produced by the reaction of CAT enzyme with methanol in the presence of $\mathrm{H}_{2} \mathrm{O}_{2}$. The principle of GPx assay depends on the indirect measure of GPx activity by a coupled reaction. GPx reduces hydroperoxide into the oxidized form glutathione (GSSG) which is recycled by NADPH into its reduced form glutathione reductase (GR). All assays were performed in triplicate.

2.6. Assessment of Cytokines and Chemokines. Sera aliquots collected from all rats were assayed for transforming growth 
factor-beta (TGF- $\beta 1$ ) as a fibrogenesis-driving cytokine [22] using an ELISA microtiter plate precoated with rat TGF- $\beta 1$ specific-specific polyclonal antibodies as per the manufacturers' instructions (Abnova, KA0416, USA). The nuclear transcription factor NF- $\kappa \mathrm{B}$ and the proinflammatory cytokine interleukin IL-6 as important signals in liver injury [23] were assayed by enzyme-linked immunosorbent assay using ELISA microtiter plates precoated with antibodies specific to NF- $\kappa \mathrm{B}$ or IL-6 according to the instructions of the manufacturer (Uscn Life Science E91824Ra, China, for NF$\kappa \mathrm{B}$ and E90079Ra for IL-6).

2.7. Assessment of Caspase-3, Proapoptotic Bax, and Antiapoptotic Bcl-2. Based on many studies, it was found that the triad Bax, Bcl-2, and caspase- 3 are involved in the apoptosis of hepatocytes during liver injury [24]. To demonstrate the effect of BR rhizome extract on the apoptosis of liver cells, rat Bax ELISA kit (Uscn Life Science E91824Ra, China), rat Bcl-2 ELISA kit (Uscn Life Science E90778Ra, China), and rat caspase-3 ELISA kit (Uscn Life Science E90626Ra, China) were applied utilizing 96-well plates precoated with monoclonal antibody specific to Bax, Bcl-2, or caspase- 3 for the evaluation of the levels of Bax, Bcl-2, and caspase-3 respectively, in the sera aliquots collected from all rats.

2.8. Evaluation of Matrix Metalloproteinase Enzymes (MMP2 and MMP-9) and TIMP-1. Matrix metalloproteinase enzymes (MMP-2 and MMP-9) and their partial regulator tissue inhibitor of metalloproteinase (TIMP-1) play a role in liver damage [25]. For this purpose, tissue homogenates were assayed for the level of these markers by monoclonal antibodies specific to the tested antigen following the kits' manuals (Uscn Life Science E90100Ra, E90553Ra, and E90552Ra, China).

2.9. Histopathological Analysis. Five $\mu \mathrm{m}$ thick sections of liver samples were prepared for Masson's trichrome (Sigma, USA) staining as a marker for detecting the degree of fibrosis [26] and observing the collagen fibers developed in liver tissues [27]. Examination of the slides was performed under a light microscope, and digital images were captured using a Nikon microscope (Y-THS, Japan) (magnification $\times 20$ ).

2.10. Immunohistochemistry. Using poly-L-lysine-coated slides, liver sections were prepared and heated in an oven (Venticell, MMM, Einrichtungen, Germany) for 25 minutes at $60^{\circ} \mathrm{C}$. After heating, liver sections were deparaffinized in xylene and rehydrated in graded alcohol. Sodium citrate buffer of concentration $10 \mathrm{mM}$ was heated till boiling in a microwave for antigen retrieval. Immunohistochemistry staining was applied following the manual of the company (DakoCytomation, USA). Succinctly, $0.03 \%$ hydrogen peroxide sodium azide was used to block the endogenous peroxidase for $5 \mathrm{~min}$ followed by washing the tissue sections carefully using wash buffer and then incubated with $\mathrm{Bcl}-$ 2 -associated $\mathrm{X}$ protein $(\mathrm{Bax})$ (1:500), proliferating cell nuclear antigen (PCNA) $(1: 200)$, and antiapoptotic protein Bcl-2 (1:50) (Santa Cruz Biotechnology Inc., California,

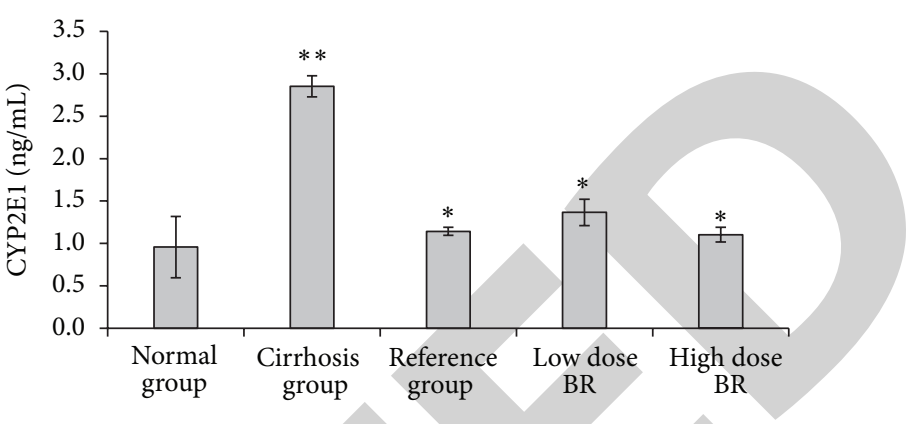

FIGURE 1: Effect of B. rotunda (BR) extract on hepatic levels of cytochrome enzyme CYP2E1 in rats at the end of the experiment. Data were expressed as mean \pm SEM. ${ }^{* *} P<0.01$ compared with the normal group. ${ }^{*} P<0.01$ compared with cirrhosis group.

USA) biotinylated primary antibodies for 15 minutes. After incubation, tissue sections were carefully rewashed with washing buffer and conserved in the buffer bath. After adding streptavidin-HRP, sections were kept for 15 minutes incubated and then washed. Diaminobenzidine substrate chromagen was applied to the sections and reincubated for over $8 \mathrm{~min}$ followed by careful washes and hematoxylin counterstaining for 5 seconds. Weak ammonia $(0.037 \mathrm{~mol} / \mathrm{L})$ was used for dipping the sections 10 times and then washed and cover slipped. Light microscopy was used to examine the brown-stained positive antigens.

2.11. Statistical Analysis. Statistical analysis of the results was performed using one-way ANOVA followed by Tukey post hoc test analysis using SPSS (Version 18, SPSS Inc., Chicago, IL, USA). A value of $P<0.05$ was considered statistically significant between the measurements of the two compared groups. All values were reported as mean \pm SEM.

\section{Results}

3.1. Hepatic Level of CYP2E1. The result of the effect of BR extract on the hepatic cytochrome enzyme CYP2E1 is shown in Figure 1. Animals from cirrhosis group had significantly $(P<0.01)$ higher levels $(2.85 \pm 0.12 \mathrm{ng} / \mathrm{mL})$ of CYP2E1 compared with normal group $(0.96 \pm 0.36 \mathrm{ng} / \mathrm{mL})$ and reference group $(1.14 \pm 0.05 \mathrm{ng} / \mathrm{mL})$. Low dose and high dose BR-treated rats showed significantly $(P<0.01)$ lower levels $(1.37 \pm 0.15$ and $1.10 \pm 0.09 \mathrm{ng} / \mathrm{mL}$, resp.) when compared with cirrhosis group.

3.2. Level of Oxidative Stress. Oxidative stress markers (hepatic nitrotyrosine and urinary $8-\mathrm{OH}-\mathrm{dG}$ ) are shown in Table 2. Generally, cirrhosis rats had significantly higher levels of oxidative stress parameters $(P<0.001)$ than normal rats and the treated groups. Remarkably, low dose and high dose-BR treated rats showed significantly lower levels $(P<$ 0.001 ) of liver nitrotyrosine and urinary $8-\mathrm{OH}-\mathrm{dG}$ compared to cirrhosis group. Moreover, no significant differences were observed in the tested oxidative stress parameters between the animals treated with the plant extract and those treated with silymarin. These results suggest that BR treatment may 


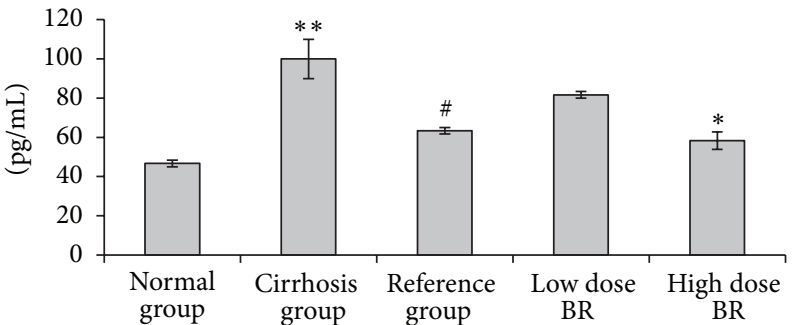

(a)

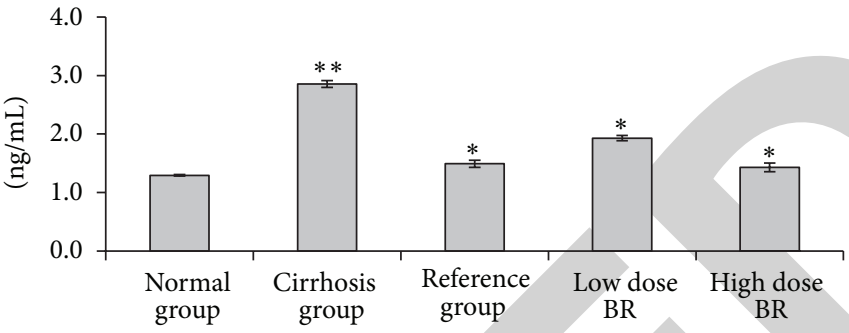

(b)

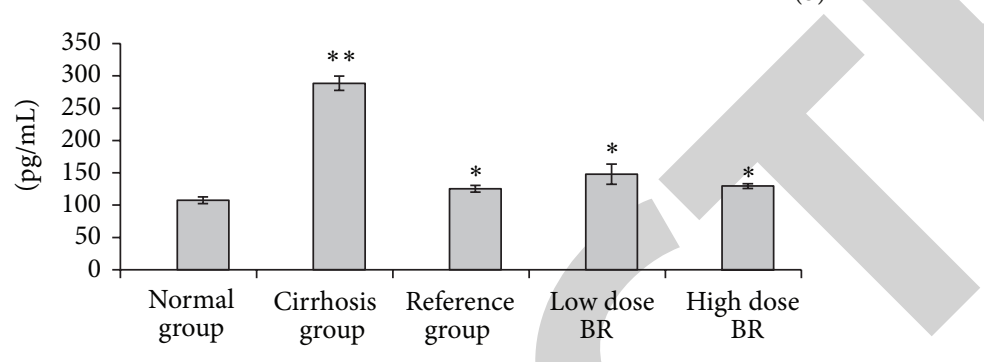

(c)

FIGURE 2: Effect of BR extract on the serum level of TGF- $\beta 1$, NF- $\kappa$ B, and IL- 6 in rats at the end of the experiment. (a) TGF- $\beta 1$, (b) NF- $\kappa$ B, and (c) IL-6. Data were expressed as mean \pm SEM. Means among groups $\left(n=6\right.$ rats/group) show significant difference. ${ }^{* *} P<0.001$ compared to the normal group. ${ }^{*} P<0.001$ compared to cirrhosis group. ${ }^{\#} P<0.01$ compared to cirrhosis group.

TABLE 2: Effect of BR extract on urine $\mathrm{OH}-\mathrm{dG}$ and liver tissue homogenate level of nitrotyrosine from the rats at the end of the experiment.

\begin{tabular}{lcc}
\hline Group & 8 -OH-dG ng/mL & Nitrotyrosine $(\mathrm{ng} / \mathrm{mL})$ \\
\hline Normal group & $2.17 \pm 0.33$ & $1.06 \pm 0.07$ \\
Cirrhosis group & $5.40 \pm 0.34^{* *}$ & $3.87 \pm 0.13^{* *}$ \\
Reference group & $2.80 \pm 0.15^{*}$ & $1.67 \pm 0.07^{*}$ \\
Low dose BR & $2.83 \pm 0.33^{*}$ & $1.40 \pm 0.20^{*}$ \\
High dose BR & $2.37 \pm 0.88^{*}$ & $1.33 \pm 0.13^{*}$ \\
\hline
\end{tabular}

8-OH-DG; 8-hydroxy-deoxyguanosine. Data are expressed as mean \pm SEM. Means among groups ( $n=6$ rats/group) show significant difference. ${ }^{*} P<$ 0.001 compared with cirrhosis group. ${ }^{* *} P<0.001$ compared with normal group.

protect liver tissues from progressive damage during liver injury.

3.3. Hepatocellular Endogenous Enzymes. Hepatocytes loss in the cirrhotic livers of rats was analyzed in another way by the activity of antioxidant enzymes CAT and GPx and the results are shown in Table 3. CAT and GPx, results were similar to that of the oxidative stress parameters but in the opposite manner, so the values of CAT and GPx in the rats of the cirrhosis group were lower than that in normal rats. These results revealed the occurrence of extensively injured hepatocytes of cirrhotic livers. Daily oral administration of low and high dose BR extract significantly $(P<0.01)$ increased the levels of CAT and GPx and induced the survival of hepatocytes. These results conjointly with our previous results of SOD [13] support the approach that treatment with BR extract could provide a healthy status for protecting the hepatic cells from advanced damage.
TABLE 3: Effect of BR extract on the liver tissue homogenate level of CAT and GPx from the rats at the end of the experiment.

\begin{tabular}{lcc} 
Group & $\begin{array}{c}\text { CAT } \\
(\mathrm{nmoL} / \mathrm{min} / \mathrm{mg} \text { protein })\end{array}$ & $\begin{array}{c}\mathrm{GPx} \\
(\mathrm{nmoL} / \mathrm{min} / \mathrm{mg} \text { protein })\end{array}$ \\
\hline $\begin{array}{l}\text { Normal } \\
\text { control }\end{array}$ & $54.00 \pm 0.36$ & $860.37 \pm 19.32$ \\
$\begin{array}{l}\text { Cirrhosis } \\
\text { control }\end{array}$ & $27.49 \pm 1.67^{* *}$ & $451.00 \pm 89.68^{\# \#}$ \\
$\begin{array}{l}\text { Reference } \\
\text { control }\end{array}$ & $52.76 \pm 3.29^{*}$ & $926.11 \pm 36.42^{*}$ \\
$\begin{array}{l}\text { Low dose BR } \\
\text { High dose BR }\end{array}$ & $41.34 \pm 2.74^{\#}$ & $902.59 \pm 69.09^{\#}$ \\
\hline
\end{tabular}

CAT: catalase, GPx: glutathione peroxidase. Data are expressed as mean \pm SEM. Means among groups ( $n=6$ rats/group) show significant difference. ${ }^{*} P<0.001$ compared with cirrhosis group. ${ }^{* *} P<0.001$ compared with normal group. ${ }^{\#} P<0.01$ compared with cirrhosis group. ${ }^{\#} P<0.01$ compared with normal group.

3.4. Cytokines and Chemokines Assessment. The serum levels of TGF- $\beta 1, N F-\kappa B$, and IL- 6 from the samples collected from all sacrificed rats are shown in Figure 2. Results showed that the serum levels of TGF- $\beta 1, \mathrm{NF}-\kappa \mathrm{B}$, and IL- 6 were significantly elevated $(P<0.05)$ in the samples from cirrhosis group $(100.00 \pm 10.00 \mathrm{pg} / \mathrm{mL}, 2.86 \pm 0.06 \mathrm{ng} / \mathrm{mL}$ and $288.58 \pm$ $11.15 \mathrm{pg} / \mathrm{mL}$, resp.) compared to the other animal groups. Administration of BR extract to animals attenuated the levels of the fibrogenesis agent TGF- $\beta 1$ to $81.67 \pm 1.67 \mathrm{pg} / \mathrm{mL}$ and the inflammatory mediators NF- $\kappa \mathrm{B}$ and IL-6 to $1.93 \pm$ $0.05 \mathrm{ng} / \mathrm{mL}$ and $148.12 \pm 15.61 \mathrm{pg} / \mathrm{mL}$, respectively, in the low dose BR-treated rats and $58.33 \pm 4.41 \mathrm{pg} / \mathrm{mL}, 1.43 \pm$ $0.07 \mathrm{ng} / \mathrm{mL}$ and $129.50 \pm 3.79 \mathrm{pg} / \mathrm{mL}$, respectively, in the high dose BR-treated rats. Levels of TGF- $\beta 1, N F-\kappa B$, and IL-6 from the high dose BR-treated group approached the 


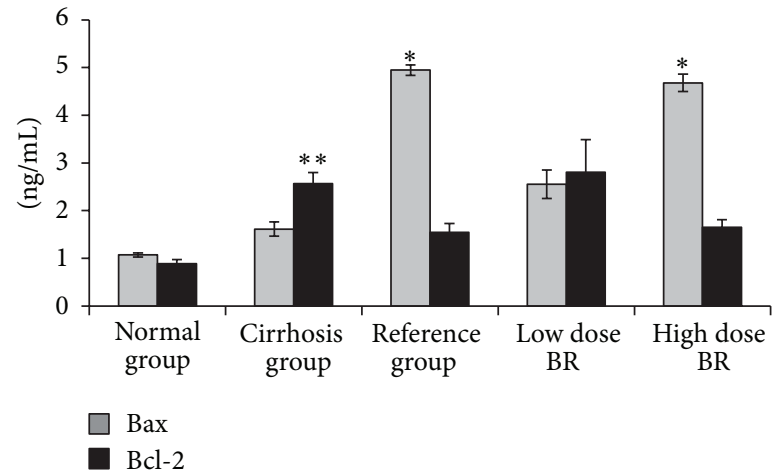

(a)

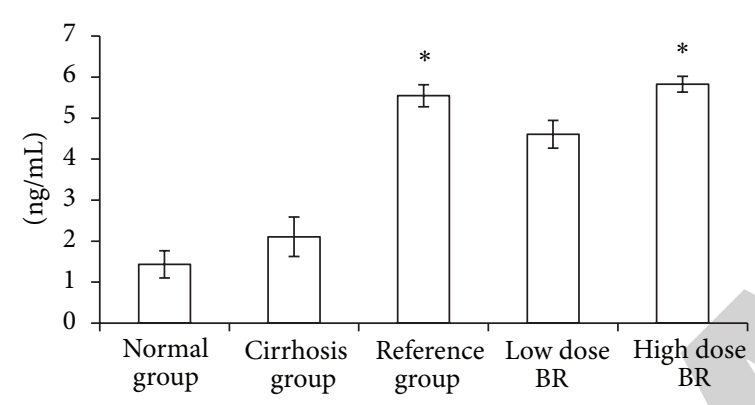

(c)

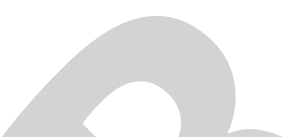

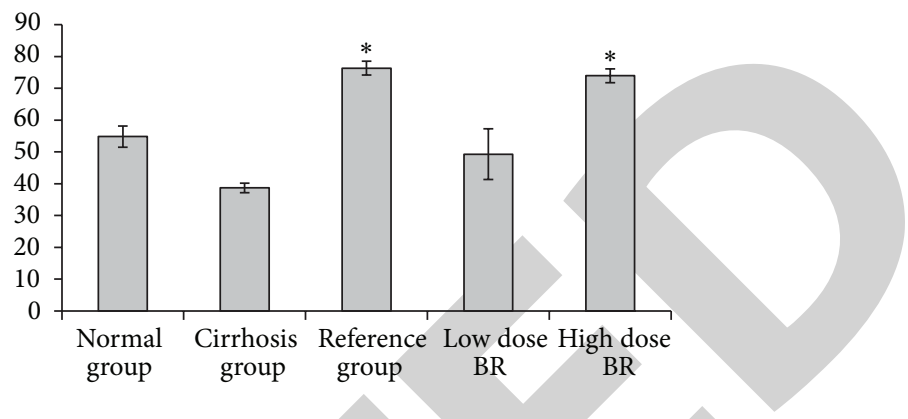

(b)

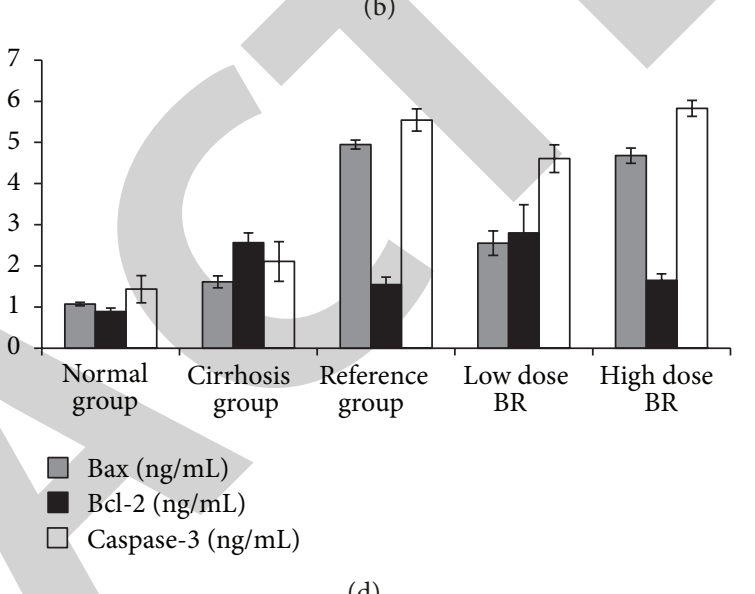

(d)

Figure 3: Effect of BR extract on the serum level of (a) Bax and Bcl-2, (b) Bax/Bcl-2 ratio, (c) caspase-3, and (d) relation between Bax, Bcl-2, and caspase- 3 at the end of the experiment. Data were expressed as mean \pm SEM. ${ }^{*} P<0.05$ compared with the cirrhosis group. ${ }^{* *} P<0.05$ compared to the normal group.

values obtained from the reference group Silymarin $(63.33 \pm$ $1.67 \mathrm{pg} / \mathrm{mL}, 1.49 \pm 0.06 \mathrm{ng} / \mathrm{mL}$, and $125.35 \pm 5.06 \mathrm{pg} / \mathrm{mL}$, resp.) compared to the higher value in the low dose BRtreated group. Results suggest that BR extract has dosedependent nature in its inhibitory effect to the profibrogenic and proinflammatory cytokines and NF- $\kappa \mathrm{B}$ chemokine.

3.5. Serum Level of Caspase-3, Bax, and Bcl-2. The levels of the proapoptotic protein Bax and the antiapoptotic protein $\mathrm{Bcl}-2$ in the rat sera are shown in Figure 3(a), and the ratio of $\mathrm{Bax} / \mathrm{Bcl}-2$ is shown in Figure $3(\mathrm{~b})$. Bax results showed no significance between cirrhosis and normal group rats $(1.61 \pm 0.15$ and $1.07 \pm 0.04 \mathrm{ng} / \mathrm{mL}$ resp. $)$. On the other hand, there was significant increase $(P<0.05)$ in the level of Bax from reference and high dose BR-treated groups $(4.95 \pm 0.11$ and $4.68 \pm 0.19 \mathrm{ng} / \mathrm{mL}$, resp.) compared to cirrhosis group. On the contrary, the level of antiapoptotic protein Bcl-2 showed significant increase $(P<0.05)$ in the cirrhosis group compared to normal group (2.57 \pm 0.23 and $0.89 \pm 0.09 \mathrm{ng} / \mathrm{mL}$, resp.), whereas no significance observed between any of the treated groups when compared with cirrhosis group indicating enhanced apoptosis in silymarin and BR-treated groups as confirmed by the ratio Bax/Bcl-2 in Figure 3(b). Furthermore, the serum level of caspase- 3 in the cirrhosis group was not significantly higher
$(2.11 \pm 0.48 \mathrm{ng} / \mathrm{mL})$ compared to normal group (1.43 \pm $0.33 \mathrm{ng} / \mathrm{mL}$ ) as illustrated in Figure 3(c). Treating the cirrhotic livers with silymarin or high dose BR elevated the caspase- 3 value to reach $5.54 \pm 0.27$ and $5.83 \pm 0.19 \mathrm{ng} / \mathrm{mL}$, respectively. The similarity observed in the results of Bax and caspase- 3 confirms the enhancement of apoptosis by $\mathrm{BR}$ extract in the same manner as the reference drug, silymarin. Figure $3(\mathrm{~d})$ shows the relation between Bax, Bcl-2, and caspase- 3 in all the experimental groups. Results showed parallel increase in the serum level of Bax and caspase- 3 in silymarin and BR groups, whereas Bcl-2 level showed reversed serum level suggesting increased apoptosis in the treated groups compared to cirrhosis control group.

3.6. Hepatic TIMP-1, MMP-9, and MMP-2. The results of the effect of BR extract treatment on the liver tissue homogenate level of MMP-2, MMP-9, and TIMP-1 collected from all experimental animals are illustrated in Table 4. From the results, the level of the tested enzymes were significantly high $(P<0.05)$ in the cirrhosis group rats compared to all other groups. On the other hand, administration of BR extract to the animals significantly $(P<0.05)$ attenuated the enzymatic levels of MMP-2, MMP-9, and TIMP-1 to approach the values of the reference control group with the exception of the low dose BR-treated group which did not show significance to 
TABLE 4: Effect of BR extract on the liver tissue homogenate level of MMP-2, MMP-9, and TIMP-1 from the rats at the end of the experiment.

\begin{tabular}{lccc}
\hline Group & $\begin{array}{c}\text { MMP-2 } \\
(\mathrm{ng} / \mathrm{mL})\end{array}$ & $\begin{array}{c}\text { MMP-9 } \\
(\mathrm{ng} / \mathrm{mL})\end{array}$ & $\begin{array}{c}\text { TIMP-1 } \\
(\mathrm{ng} / \mathrm{mL})\end{array}$ \\
\hline Normal control & $2.65 \pm 1.07$ & $9.01 \pm 2.34$ & $1.42 \pm 0.55$ \\
Cirrhosis control & $8.43 \pm 0.86^{* *}$ & $45.61 \pm 1.88^{* *}$ & $6.09 \pm 1.35^{* *}$ \\
Reference control & $3.34 \pm 0.13^{*}$ & $16.72 \pm 2.43^{*}$ & $1.77 \pm 0.06^{*}$ \\
Low dose B. rotunda & $5.86 \pm 0.26$ & $30.21 \pm 4.43^{*}$ & $2.06 \pm 0.19^{*}$ \\
High dose B. rotunda & $3.86 \pm 0.69^{*}$ & $14.80 \pm 2.30^{*}$ & $1.82 \pm 0.05^{*}$ \\
\hline
\end{tabular}

MMP-2: matrix metalloproteinase-2, MMP-9: matrix metalloproteinase-9, TIMP-1: metalloproteinase inhibitor-1. Data are expressed as mean \pm SEM. Means among groups ( $n=6$ rats/group) show significant difference. ${ }^{*} P<$ 0.05 compared to cirrhosis group. ${ }^{* *} P<0.05$ compared with normal group.

cirrhosis group indicating the efficacy of the plant extract treatment in a dose-dependent manner. Results in Table 4 showed parallel decrease in the hepatic level of MMP-2, MMP-9, and TIMP-1 from BR-treated groups.

3.7. Masson's Trichrome Staining. The degree of fibrosis determined by Masson's trichrome staining of the liver sections from all the treated groups is shown in Figure 4. Liver sections from normal rats appeared normal without signs of collagen deposition. Liver sections from the cirrhosis rats of cirrhosis group revealed increased deposition of collagen fibers around the congested central vein indicating severe fibrosis. Liver tissues from the reference group showed minimal collagen deposition indicating minimal fibrosis. Livers from rats treated with low dose BR extract showed moderate deposition of collagen fibers and moderate congestion around the central vein, while those from rats treated with high dose BR extract showed mild collagen deposition and mild congestion around the central vein. This measurement of the degree of fibrosis confirms the previous findings that treatment with $\mathrm{BR}$ extract might protect the animals' liver from development of fibrosis.

3.8. Immunohistochemistry. Bax, $\mathrm{Bcl}-2$, and PCNA staining of liver cells from all animal groups are shown in Figures 5(a), 5(b), and 6. Hepatocytes of liver tissues from cirrhosis group rats showed downregulation of Bax staining with upregulation of Bcl-2-positive hepatocytes and more PCNA staining indicating severe necrosis with high cell proliferation to repair the damaged hepatocytes. Hepatocytes from the reference group (Silymarin-treated rats) showed upregulated Bax expression, downregulated Bcl-2 expression, and few PCNA staining indicating lower levels of proliferation of necrotized hepatocytes proliferation than apoptosis. Liver tissues treated with low dose and high dose BR extract induced hepatocyte apoptosis as indicated by the upregulated Bax expression, downregulated $\mathrm{Bcl}-2$, and downregulated proliferation of necrotic hepatocytes as indicated by reduced PCNA staining. These findings support the idea of BR extractinduced hepatoprotective activities against progressive liver damage by increasing apoptosis of damaged hepatocytes and ameliorating their proliferation.

\section{Discussion}

Liver cirrhosis has become a serious health problem because of the wider use of prescribed medications with adverse reactions in modern life of today or the drug misuse. Consequently, the current research has targeted on finding new therapeutic alternatives and analyzing their mechanism to get rid of the signaling routes and reduce the loss induced on the liver [28]. Beyond the techniques with artificial pharmacology, the search also chases alternative techniques that depend on natural products. In particular, it targets those plants with known medical history or confirmed prospective of positive results against the illnesses of the liver or other body parts [29]. To aid these initiatives, in this study, we analyzed the mechanism of ethanol extract of BR rhizomes as a promising therapy for treating liver cirrhosis.

Thioacetamide is biotransformed by CYP2E1 enzymes located in the microsomes of liver cells and convert it to a highly reactive toxic intermediate known as thioacetamide sulphur dioxide through oxidation [30], inducing hepatotoxicity in experimental animals and different grades of liver damage including nodular cirrhosis, production of pseudolobules, proliferation of hepatic cells, and necrosis of parenchyma cells [31]. All experimental animals in the present study were tested for CYP2E1 enzyme level in liver homogenate tissues (Figure 1). Efficacy of BR extract in comparison with silymarin control was able to inhibit metabolism of TAA, which might be one of the significant factors in hepatoprotective activity by blocking the release of toxic metabolites and ROS responsible for inducing damage of hepatocytes [32].

Reactive oxygen species (ROS) and reactive nitrogen species (RNS) production increase during liver injury by transformation of xenobiotics such as $\mathrm{CCl}_{4}$, ethanol, and acetaminophen in the liver and play a crucial role in the death of hepatocytes [33]. TAA induces hepatocyte damage via its metabolite, $\mathrm{TASO}_{2}$, which damages the macromolecules of hepatocytes causing damage of DNA molecules, oxidation of protein molecules, and peroxidation of the cell membrane biomolecules $[34,35]$. This study evaluated the oxidative stress markers and observed the degree of liver cells damage. The levels of urine 8-OH-dG and nitrotyrosine (Table 2) were high in the cirrhosis group compared to the treated groups. This supported the crude extract antioxidants mechanism in downregulating ROS, inhibiting DNA damage, and attenuating protein and lipid oxidation [36]. Furthermore, the antioxidant constituents of BR extract helped in boosting the hepatocellular endogenous enzymes (CAT and GPx) as shown in Table 3.

Toxins target metabolically effective hepatic cells causing dysfunction of hepatocytes and the discharge of inflammation-related cytokines as NF- $\kappa$ B and IL- 6 and fibrogenic mediators as TGF- $\beta 1$. Many researchers have recommended that part of liver injury brought on by TAA is mediated through oxidative stress and the effect of cytokines via fat peroxidation $[37,38]$. The free radicals released as the consequences of TAA metabolism in liver cells activate myofibroblasts that secrete fibrinogen and growth factors [39]. The present study revealed that BR extract treatment 


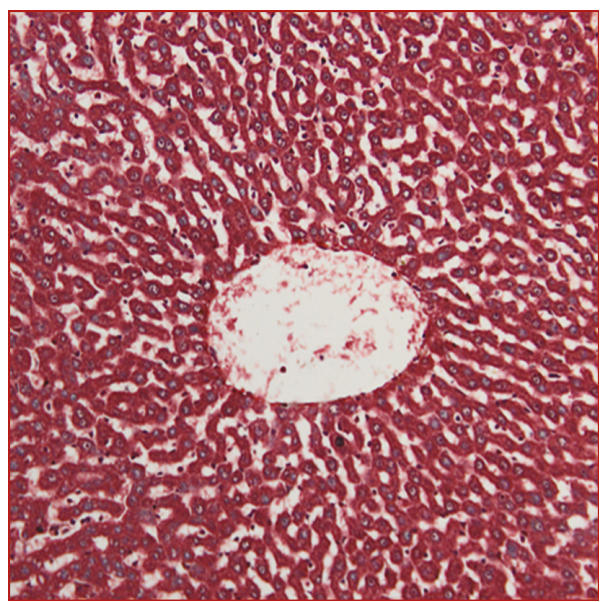

(a)

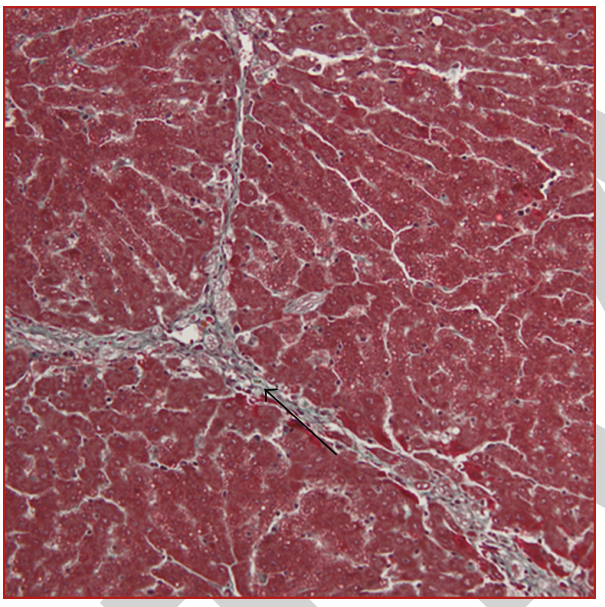

(c)

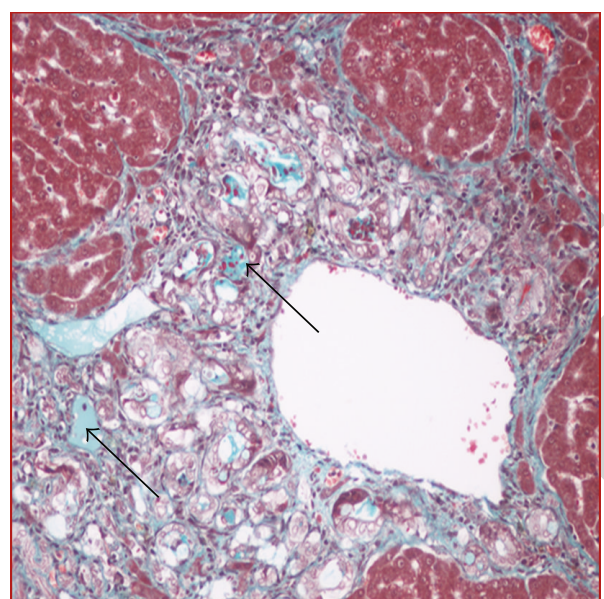

(b)

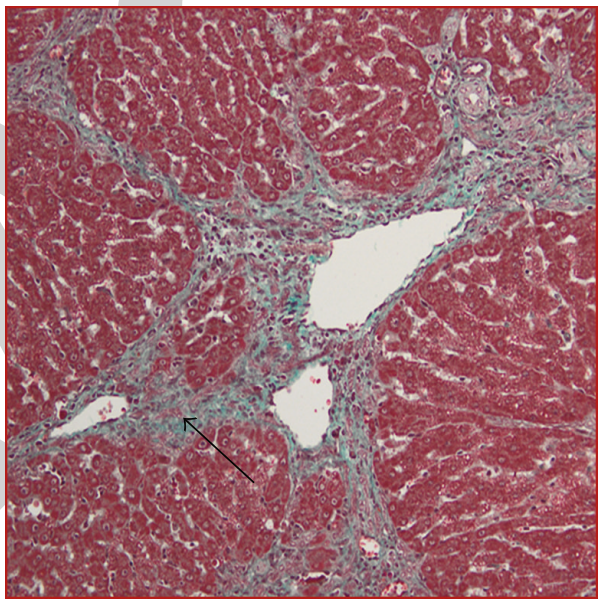

(d)
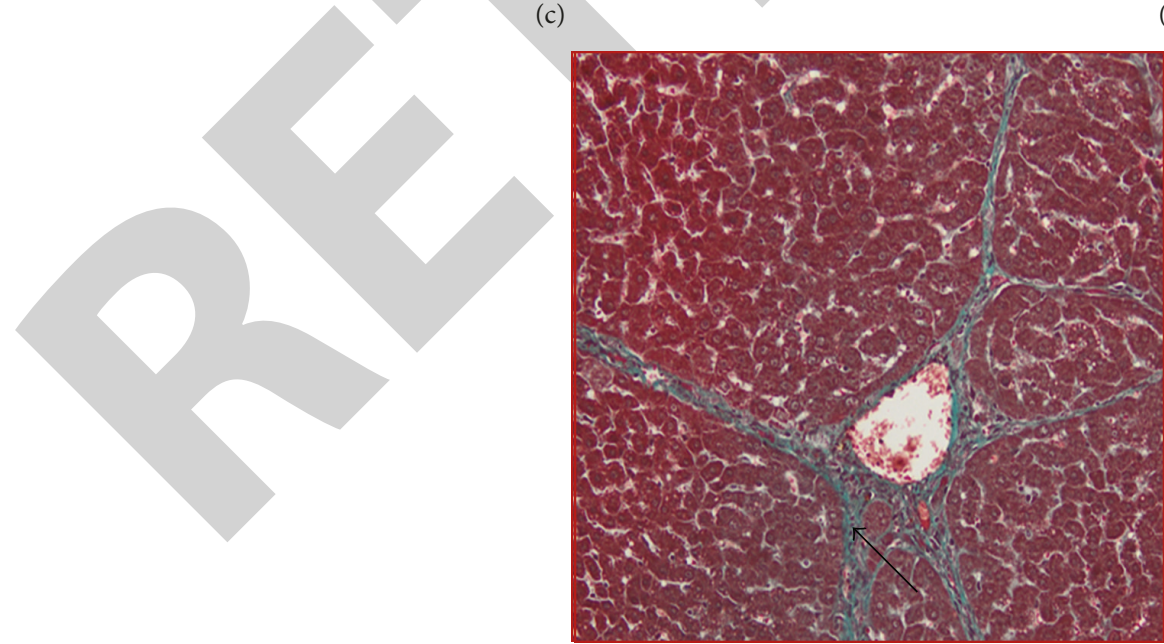

(e)

FIGURE 4: Masson's trichrome staining of representative livers sampled from rats in different experimental groups. (a) Normal liver did not show signs of collagen deposition in livers from a normal rat. (b) Severe collagen deposition (arrow) and severe fibrosis were seen in the livers from a cirrhosis rat. (c) Minor collagen deposition in the liver of a hepatoprotected rat treated with Silymarin. (d) Moderated collagen deposition and moderate congestion around the central vein in the liver of rats treated with low dose BR extract. (e) Mild collagen deposition was observed in the livers of rats treated with high dose BR extract (original magnification $\times 20$ ). 


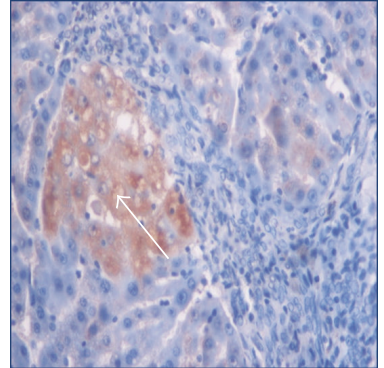

(i)

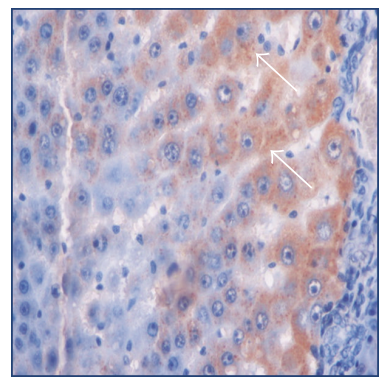

(ii)

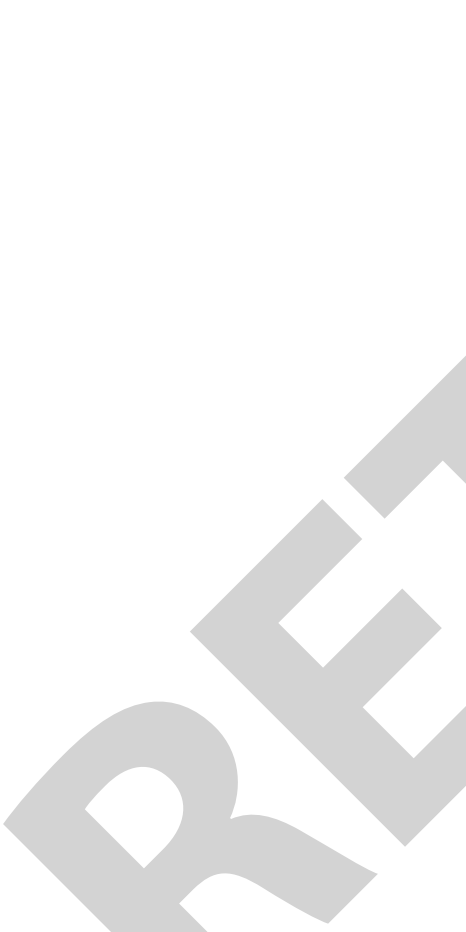

(iii)

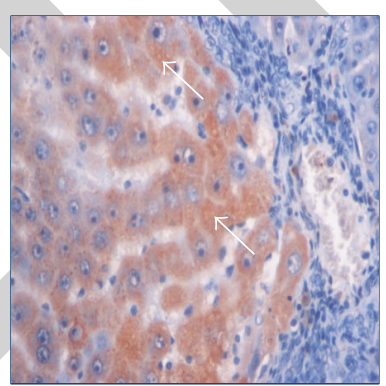

(iv)

(a)

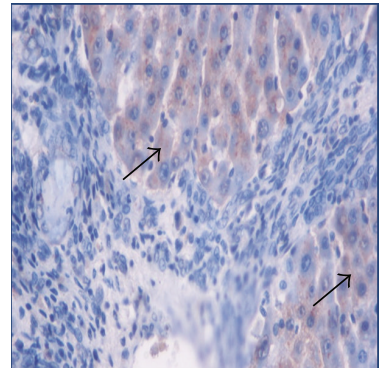

(i)

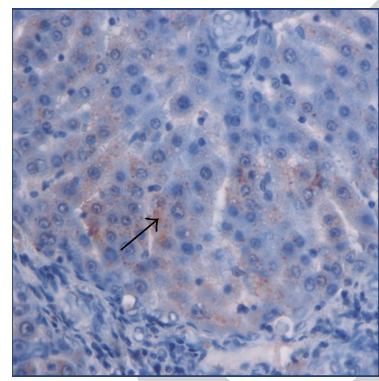

(ii)

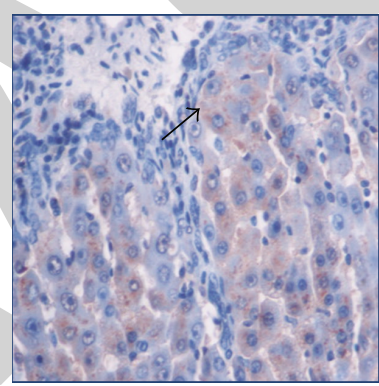

(iii)

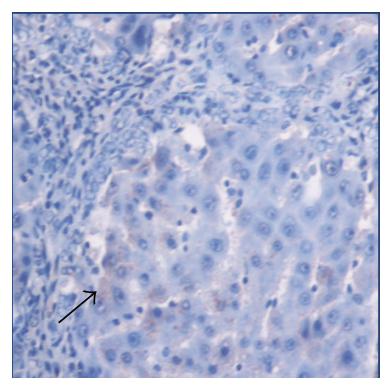

(iv)

(b)

FigURE 5: Immunohistochemistry staining of (a) Bax and (b) Bcl-2 of representative livers sampled from rats in different experimental groups. Less apoptosis indicated by (ia) few Bax-positive hepatocytes (white arrow) and (ib) more Bcl-2-positive hepatocytes (black arrow) in liver tissues from a cirrhosis rat group. (iia) High numbers of Bax-positive hepatocytes (White arrow) and (iib) very less Bcl-2-positive hepatocytes (black arrow) in the liver from a hepatoprotected rat treated with Silymarin. Moderate apoptosis as indicated by (iiia) moderate Bax staining (white arrow) and (iiib) moderate Bcl-2 staining (black arrow) indicating moderate apoptosis in the liver from the rats treated with low dose BR extract. (iva) High numbers of Bax-positive cells (white arrow) with severe apoptosis and (ivb) very less Bcl-2-positive hepatocytes (black arrow) were observed in the liver of the rats treated with high dose BR extract (original magnification $\times 40$ ).

attenuated level of the prominent profibrogenic cytokine TGF- $\beta 1$ (Figure 2 ) indicating the inhibitory activity of BR extract to the proliferative activity of HSCs which might be confirmed by the less collagen deposition in the liver tissues of animals treated with BR extract (Figure 4). Similarly, the high levels of proinflammatory cytokines IL- 6 and NF- $\kappa$ B
(Figure 2) observed in the cirrhosis group rats were reversed in the rats treated with $\mathrm{BR}$ extract indicating the antiinflammatory activity of BR extract.

A number of studies have focused on the molecular regulation of apoptosis. One of the characteristic features of liver diseases is the death of hepatocytes as a response 


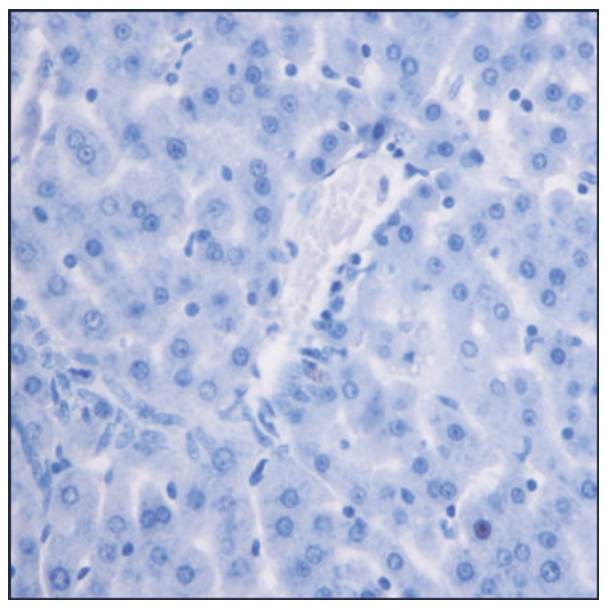

(a)

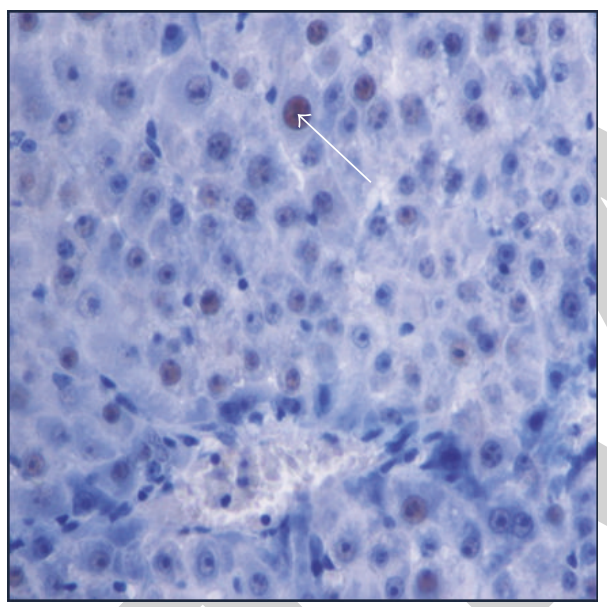

(c)

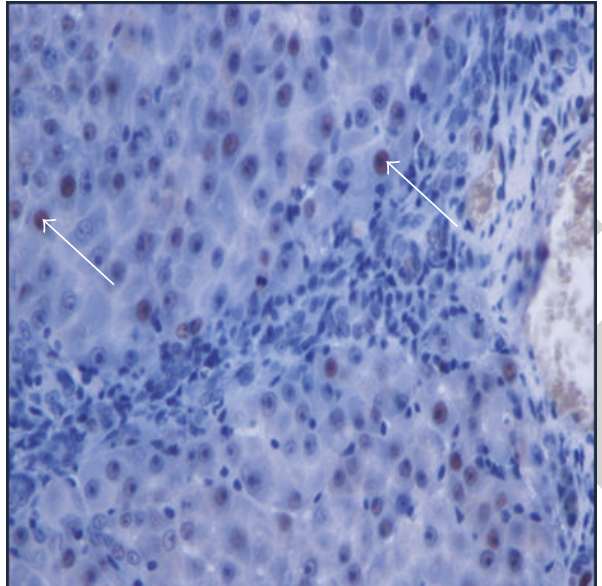

(b)

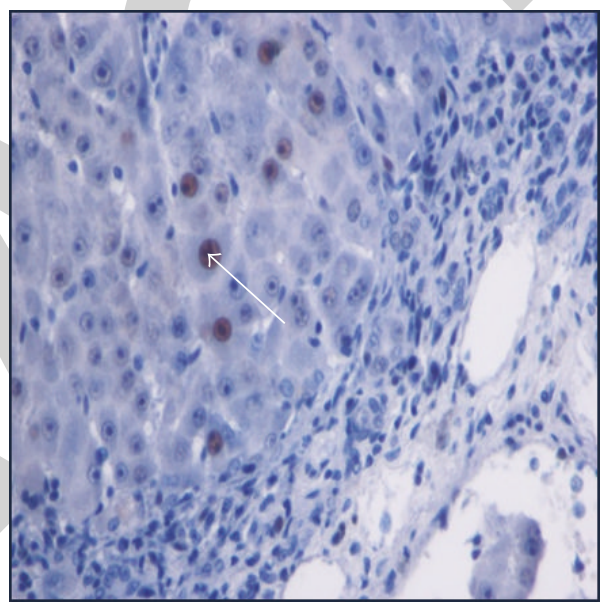

(d)

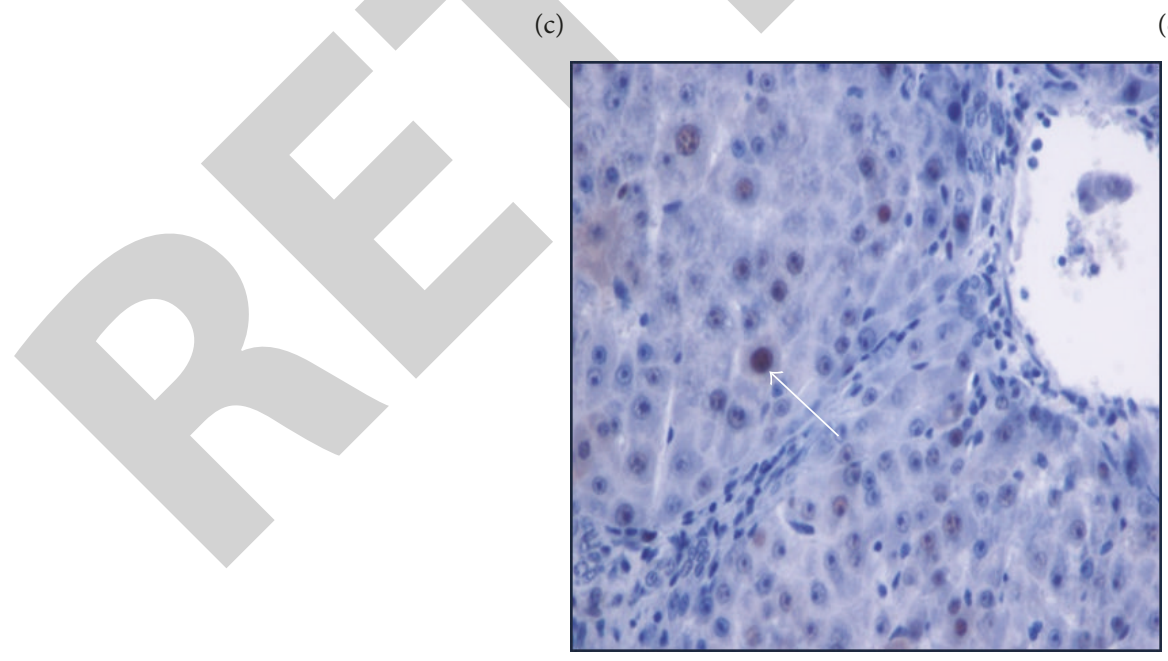

(e)

FIGURE 6: Immunohistochemistry staining of PCNA of livers sampled from rats in different experimental groups. (a) Normal livers did not show signs of PCNA expression in hepatocytes from control rats. (b) Cirrhosis control liver showed severe fibrosis with greater PCNA expression in the necrotized hepatocytes. (c) Silymarin-treated liver showed less PCNA-stained hepatocytes (arrow) indicating less hepatocyte proliferation. (d) The low dose BR-treated liver showed moderate hepatocyte proliferation as indicated by moderate PCNA staining (arrow) in the hepatocytes. (e) High dose BR-treated livers showed minor PCNA expression (arrow) with few proliferated necrotized hepatocytes which were observed in the liver (original magnification $\times 40$ ). 


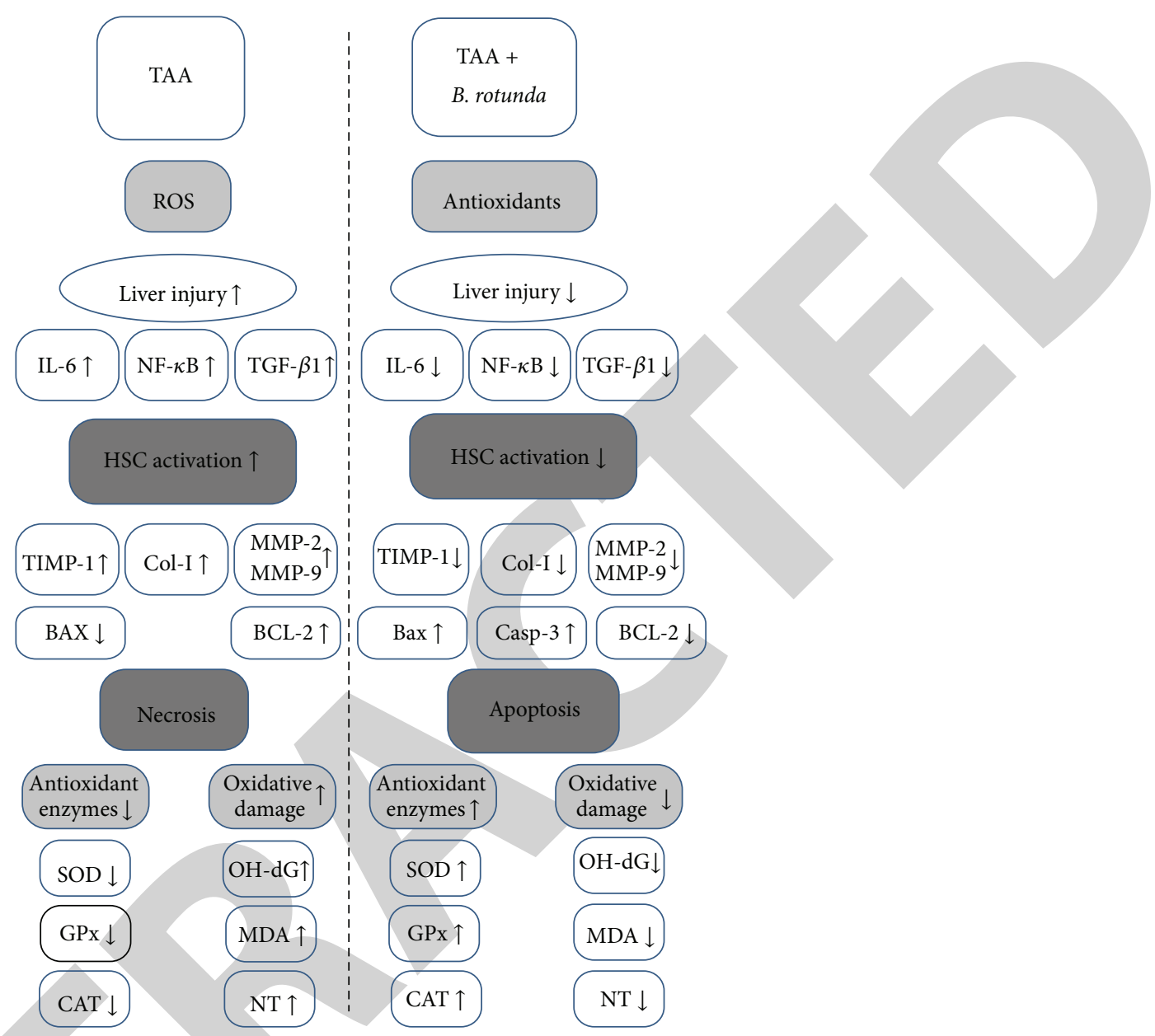

FIGURE 7: Possible mechanism of hepatoprotective effect of Boesenbergia rotunda on TAA-induced liver damage in rats.

to drug/toxicant-induced liver injury. Cytotoxic drugs and cellular stress activate the intrinsic mitochondrial apoptotic pathway [40] so that the inhibitors of Bcl-2 activate caspase3 initiating apoptosis, whereas inducers of $\mathrm{Bcl}-2$ induce necrosis of cells [41]. In vivo, necrotic death is often associated with extensive damage in the tissue resulting in necroinflammatory response [42]. Although toxicity induced by TAA was reported to cause upregulation of Bax protein and downregulation of the antiapoptotic protein $\mathrm{Bcl}-2$ and its translocation into the mitochondria, causing apoptosis [43] but other studies suggested that the ROS produced from thioacetamide biotransformation causes centrolobular necrosis [44]. Some Plant extracts such as Curcuma longa extract [4] and some antioxidants such as $\alpha$-lipoic acid [45], curcumin, and curcuminoids [46] were proved to induce apoptosis. In the current study, we observed significant increase in the serum level of Bax protein and caspase- 3 and decrease in Bcl-2 protein in the BR-treated and silymarintreated animals compared to cirrhosis group animals as shown in the relation between $\mathrm{Bax}, \mathrm{Bcl}-2$, and caspase- 3 in Figure 3(d). This was confirmed by the ratio Bax/Bcl-2 (Figure 3(b)) which was high in the treated groups compared to cirrhosis group and the immunohistochemistry staining of $\mathrm{Bax}$ and $\mathrm{Bcl}-2$ (Figure 5). The ethanolic extract of BR rhizomes might contain active compounds such as the chalcone Boesenbergin A [47] and the sesquiterpene zerumbone [48] which were reported recently to induce apoptosis of liver cancer cells HepG2 through the release of cytochrome $\mathrm{C}$ and the formation of caspase- 3 modifying the necrotic effect due to TAA intoxication to apoptosis. This modification in vivo would scale down the release of inflammatory mediators that would prevent progressive liver damage. Furthermore, feeding of rats daily with BR extract along with TAA injections 3 times/week for 8 weeks inhibited proliferation of hepatocytes as indicated by the significant reduction of PCNA staining in the liver sections from the plant extracts-treated groups similar to that in the Silymarin-treated group (Figure 6) [49]. Downregulation of cell proliferation in BR-treated rats may be attributed to the reduced damage in the $\mathrm{BR}$-treated livers compared to the higher damage of hepatocytes and the upregulation of PCNA in the cirrhosis animals to regenerate the necrotic effect of TAA to hepatocytes.

In liver fibrosis, there is an imbalance between excess deposition and/or a decrease in the extracellular matrix (ECM) removal with consequent scarring damage [50]. ECM is mainly controlled by matrix metalloproteinases (MMPs), which are a group of proteolytic enzymes that are able 
to degrade the ECM [51, 52]. MMP-9 and TIMP-1 were verified as the molecular signatures during the progress of liver cirrhosis induced by TAA [53]. Park et al. observed that TAA increased MMP-2 expression in the liver tissues of rats and reported that the balance of MMPs and TIMPs is the key factor of liver fibrogenesis [50]. In this research, administered animals with plants extract showed significant downregulation in the hepatic level of TIMP-1, MMP-9 and MMP-2 similar to silymarin reference group (Table 4). Results suggest that the efficacy of BR extract might be due to the inhibition of HSCs and kupffer cells activity and their secretion to MMP-2 and MMP-9, respectively. In addition, reduced activity of HSCs as indicated by the decreased level of collagen deposition in the BR-treated liver tissues has led to down-regulation of TIMP-1 [54]. Furthermore, the reduced activity of kupffer cells was indicated by the significant inhibitory effect of BR extract to the mediators TGF- $\beta 1$, IL6 , and NF- $\kappa \mathrm{B}$ levels in rat serum. Consequently, the low level of these mediators might have contributed to HSCs activation and reduced liver injury [19]. Figure 7 summarizes the effect of BR treatment on the liver damage induced by TAA intoxication.

Due to the crucial role played by HSCs in liver fibrosis via their resistance to apoptosis, recent treatment strategies of liver diseases are to inhibit their proliferation or induce their apoptosis. The biochemical findings of our study were confirmed by the histopathological examinations of rat liver tissues (Figure 4) showing that livers from BR-treated rats had nearly normal liver architecture with significant reduction in collagen synthesis. This was probably due to the inhibitory effect of the plant extract on hepatic stellate cell activation. Inhibition of HSC activation and downregulation of collagen-I in the livers treated with BR extract might be due to the activity of polyphenol constituents in BR extract [55].

\section{Conflict of Interests}

The authors declare that they have no financial conflict of interests.

\section{Acknowledgments}

This study was financially supported by the University of Malaya through University Malaya Research Grant PV0422011A and HIR Grant (F000009-21001). The authors are thankful to the staffs of Department of Molecular Medicine and Clinical Diagnostic Laboratory of University Malaya.

\section{References}

[1] C. L. Raison, M. Demetrashvili, L. Capuron, and A. H. Miller, "Neuropsychiatric adverse effects of interferon- $\alpha$ : recognition and management," CNS Drugs, vol. 19, no. 2, pp. 105-123, 2005.

[2] H. Yang, S. H. Sung, and Y. C. Kim, "Two new hepatoprotective stilbene glycosides from Acer mono leaves," Journal of Natural Products, vol. 68, no. 1, pp. 101-103, 2005.

[3] N. Wang, P. Li, Y. Wang et al., "Hepatoprotective effect of Hypericum japonicum extract and its fractions," Journal of Ethnopharmacology, vol. 116, no. 1, pp. 1-6, 2008.
[4] S. M. Salama, M. A. Abdulla, A. S. AlRashdi, S. Ismael, S. S. Alkiyumi et al., "Hepatoprotective effect of ethanolic extract of Curcuma longa on thioacetamide induced liver cirrhosis in rats," BMC Complementary and Alternative Medicine, vol. 13, articel 56, 2013.

[5] M. A. Alshawsh, M. A. Abdulla, S. Ismail, and Z. A. Amin, "Hepatoprotective effects of Orthosiphon stamineus extract on thioacetamide-induced liver cirrhosis in rats," Evidence-based Complementary and Alternative Medicine, vol. 2011, Article ID 103039, 2011.

[6] Z. A. Amin, M. Bilgen, M. A. Alshawsh, H. M. Ali, A. H. A. Hadi et al., "Protective role of Phyllanthus niruri extract against thioacetamide-induced liver cirrhosis in rat model," Evidence-Based Complementary and Alternative Medicine, vol. 2012, Article ID 241583, 9 pages, 2012.

[7] H. S. Rho, A. K. Ghimeray, D. S. Yoo et al., "Kaempferol and kaempferol rhamnosides with depigmenting and antiinflammatory properties," Molecules, vol. 16, no. 4, pp. 33383344, 2011.

[8] A. Y. L. Ching, S. W. Tang, M. A. Sukari, G. E. C. Lian, M. Rahmani et al., "Characterization of flavonoid derivatives from Boesenbergia rotunda (L.)," The Malaysian Journal of Analytical Sciences, vol. 11, pp. 154-159, 2007.

[9] K. Shindo, M. Kato, A. Kinoshita, A. Kobayashi, and Y. Koike, "Analysis of antioxidant activities contained in the Boesenbergia pandurata Schult. rhizome," Bioscience, Biotechnology and Biochemistry, vol. 70, no. 9, pp. 2281-2284, 2006.

[10] S. P. Voravuthikunchai, S. Phongpaichit, and S. Subhadhirasakul, "Evaluation of antibacterial activities of medicinal plants widely used among AIDS patients in Thailand," Pharmaceutical Biology, vol. 43, no. 8, pp. 701-706, 2005.

[11] A. Mahmood, A. A. Mariod, S. I. Abdelwahab, S. Ismail, and F. Al-Bayaty, "Potential activity of ethanolic extract of Boesenbergia rotunda (L.) rhizomes extract in accelerating wound healing in rats," Journal of Medicinal Plants Research, vol. 4, pp. 15701576, 2010.

[12] S. I. Abdelwahab, S. Mohan, M. A. Abdulla et al., "The methanolic extract of Boesenbergia rotunda (L.) Mansf. and its major compound pinostrobin induces anti-ulcerogenic property in vivo: possible involvement of indirect antioxidant action," Journal of Ethnopharmacology, vol. 137, no. 2, pp. 963-970, 2011.

[13] S. M. Salama, M. Bilgen, A. S. Al Rashdi, and M. A. Abdulla, "Efficacy of Boesenbergia rotunda treatment against thioacetamide-induced liver cirrhosis in a rat model," EvidenceBased Complementary and Alternative Medicine, vol. 2012, Article ID 137083, 12 pages, 2012.

[14] S. C. Pradhan and C. Girish, "Hepatoprotective herbal drug, silymarin from experimental pharmacology to clinical medicine," Indian Journal of Medical Research, vol. 124, pp. 491-504, 2006.

[15] A. F. Aydın, Z. Küskü-Kiraz, S. Doğru-Abbasoğlu, M. Güllüoğlu, M. Uysal et al., "Effect of carnosine against thioacetamide-induced liver cirrhosis in rat," Peptides, vol. 31, pp. 67-71, 2010.

[16] O. H. Lowry, N. J. Rosebrough, A. L. Farr, and R. J. Randall, "Protein measurement with the Folin phenol reagent," The Journal of Biological Chemistry, vol. 193, no. 1, pp. 265-275, 1951.

[17] A. A. Amali, R. D. Rekha, C. J.-F. Lin et al., "Thioacetamide induced liver damage in zebrafish embryo as a disease model for steatohepatitis," Journal of Biomedical Science, vol. 13, no. 2, pp. 225-232, 2006. 
[18] R. K. Sindhu, J.-R. Koo, K. K. Sindhu, A. Ehdaie, F. Farmand, and C. K. Roberts, "Differential regulation of hepatic cytochrome P450 monooxygenases in streptozotocin-induced diabetic rats," Free Radical Research, vol. 40, no. 9, pp. 921-928, 2006.

[19] R. Bruck, M. Ashkenazi, S. Weiss et al., "Prevention of liver cirrhosis in rats by curcumin," Liver International, vol. 27, no. 3, pp. 373-383, 2007.

[20] L. L. Wu, C.-C. Chiou, P.-Y. Chang, and J. T. Wu, "Urinary 8OHdG: a marker of oxidative stress to DNA and a risk factor for cancer, atherosclerosis and diabetics," Clinica Chimica Acta, vol. 339, no. 1-2, pp. 1-9, 2004.

[21] L. A. Pham-Huy, H. He, and C. Pham-Huy, "Free radicals, antioxidants in disease and health," International Journal of Biomedical Science, vol. 4, no. 2, pp. 89-96, 2008.

[22] O. A. Gressner, R. Weiskirchen, and A. M. Gressner, "Evolving concepts of liver fibrogenesis provide new diagnostic and therapeutic options," Comparative Hepatology, vol. 6, article 7, 2007.

[23] P. Mandrekar and G. Szabo, "Signalling pathways in alcoholinduced liver inflammation," Journal of Hepatology, vol. 50, no. 6, pp. 1258-1266, 2009.

[24] A. M. Elsharkawy, F. Oakley, and D. A. Mann, “The role and regulation of hepatic stellate cell apoptosis in reversal of liver fibrosis," Apoptosis, vol. 10, no. 5, pp. 927-939, 2005.

[25] I. Okazaki, Y. Ninomiya, T. Kyuichi, and S. I. Friedman, Extracellular Matrix and the Liver: Approach To Gene Therapy, Academic Press, 2003.

[26] M. Zeisberg, C. Yang, M. Martino et al., "Fibroblasts derive from hepatocytes in liver fibrosis via epithelial to mesenchymal transition," Journal of Biological Chemistry, vol. 282, no. 32, pp. 23337-23347, 2007.

[27] K. L. Edgtton, R. M. Gow, D. J. Kelly, P. Carmeliet, and A. R. Kitching, "Plasmin is not protective in experimental renal interstitial fibrosis," Kidney International, vol. 66, no. 1, pp. 6876, 2004.

[28] A. K. Daly, P. T. Donaldson, P. Bhatnagar et al., "HLA-B5701 genotype is a major determinant of drug-induced liver injury due to flucloxacillin," Nature Genetics, vol. 41, no. 7, pp. 816-819, 2009.

[29] D. Khanna, G. Sethi, K. S. Ahn et al., "Natural products as a gold mine for arthritis treatment," Current Opinion in Pharmacology, vol. 7, no. 3, pp. 344-351, 2007.

[30] K.-H. Kim, J.-H. Bae, S.-W. Cha, S.-S. Han, K. H. Park, and T. C. Jeong, "Role of metabolic activation by cytochrome P450 in thioacetamide-induced suppression of antibody response in male BALB/c mice," Toxicology Letters, vol. 114, no. 1-3, pp. 225$235,2000$.

[31] S. Sadasivan, P. G. Latha, J. M. Sasikumar, S. Rajashekaran, S. Shyamal, and V. J. Shine, "Hepatoprotective studies on Hedyotis corymbosa (L.) Lam,” Journal of Ethnopharmacology, vol. 106, no. 2, pp. 245-249, 2006.

[32] P. N. Karamanakos, D. T. P. Trafalis, G. D. Geromichalos et al., "Inhibition of rat hepatic CYP2E1 by quinacrine: molecular modeling investigation and effects on 4-(methyl nitrosamino)-1-(3-pyridyl)-1-butanone (NNK)-induced mutagenicity," Archives of Toxicology, vol. 83, no. 6, pp. 571-580, 2009.

[33] P. Muriel, "Role of free radicals in liver diseases," Hepatology International, vol. 3, no. 4, pp. 526-536, 2009.

[34] J. Chilakapati, M. C. Korrapati, R. A. Hill, A. Warbritton, J. R. Latendresse, and H. M. Mehendale, "Toxicokinetics and toxicity of thioacetamide sulfoxide: a metabolite of thioacetamide," Toxicology, vol. 230, no. 2-3, pp. 105-116, 2007.

[35] V. B. Djordjević, "Free radicals in cell biology," International Review of Cytology, vol. 237, pp. 57-89, 2004.

[36] A. Mori, I. Yokoi, Y. Noda, and L. J. Willmore, "Natural antioxidants may prevent posttraumatic epilepsy: a proposal based on experimental animal studies," Acta Medica Okayama, vol. 58, no. 3, pp. 111-118, 2004.

[37] H. M. Mehendale, "Tissue repair: an important determinant of final outcome of toxicant-induced injury," Toxicologic Pathology, vol. 33, no. 1, pp. 41-51, 2005.

[38] H. Okuyama, Y. Shimahara, H. Nakamura, S. Araya, N. Kawada et al., "Thioredoxin prevents thioacetamide-induced acute hepatitis," Comparative Hepatology, vol. 3, Supplement 1, p. S6, 2004.

[39] A. R. Bassiouny, A. Z. Zaky, S. A. Abdulmalek, K. M. Kandeel, A. Ismail, and M. Moftah, "Modulation of AP-endonuclease1 levels associated with hepatic cirrhosis in rat model treated with human umbilical cord blood mononuclear stem cells," International Journal of Clinical and Experimental Pathology, vol. 4, no. 7, pp. 692-707, 2011.

[40] M. H. Kang and C. P. Reynolds, "BcI-2 Inhibitors: targeting mitochondrial apoptotic pathways in cancer therapy," Clinical Cancer Research, vol. 15, no. 4, pp. 1126-1132, 2009.

[41] M. Emi, R. Kim, K. Tanabe, Y. Uchida, and T. Toge, "Targeted therapy against Bcl-2-related proteins in breast cancer cells," Breast Cancer Research, vol. 7, pp. R940-R952, 2005.

[42] J. D. Choudhury, S. Kumar, V. Mayank, J. Mehta, and D. Bardalai, "A review on apoptosis and its different pathway," International Journal of Biological and Pharmaceutical Research, vol. 3, pp. 848-861, 2012.

[43] L.-H. Chen, C.-Y. Hsu, and C.-F. Weng, "Involvement of P53 and $\mathrm{Bax} / \mathrm{Bad}$ triggering apoptosis in thioacetamide-induced hepatic epithelial cells," World Journal of Gastroenterology, vol. 12, no. 32, pp. 5175-5181, 2006.

[44] M. K. Sarkar and P. C. Sil, "Hepatocytes are protected by herb Phyllanthus niruri protein isolate against thioacetamide toxicity," Pathophysiology, vol. 14, no. 2, pp. 113-120, 2007.

[45] J. Moungjaroen, U. Nimmannit, P. S. Callery et al., "Reactive oxygen species mediate caspase activation and apoptosis induced by lipoic acid in human lung epithelial cancer cells through Bcl-2 down-regulation," Journal of Pharmacology and Experimental Therapeutics, vol. 319, no. 3, pp. 1062-1069, 2006.

[46] M.-E. Wang, Y.-C. Chen, I.-S. Chen, S.-C. Hsieh, S.-S. Chen, and C.-H. Chiu, "Curcumin protects against thioacetamideinduced hepatic fibrosis by attenuating the inflammatory response and inducing apoptosis of damaged hepatocytes," Journal of Nutritional Biochemistry, vol. 23, pp. 1352-1366, 2012.

[47] K. Ng -B, A. Bustamam, M. A. Sukari, S. I. Abdelwahab, S. Mohan et al., "Induction of selective cytotoxicity and apoptosis in human T4-lymphoblastoid cell line (CEMss) by boesenbergin a isolated from Boesenbergia rotunda rhizomes involves mitochondrial pathway, activation of caspase 3 and G2/M phase cell cycle arrest," BMC Complementary and Alternative Medicine, vol. 13, article 41, 2013.

[48] N. Muhammad Nadzri, A. B. Abdul, M. A. Sukari, S. I. Abdelwahab, E. E. Eid et al., "Inclusion Complex of Zerumbone with Hydroxypropyl-beta-Cyclodextrin Induces Apoptosis in Liver Hepatocellular HepG2 Cells via Caspase 8/BID Cleavage Switch and Modulating Bcl2/Bax Ratio," Evidence-Based Complementary and Alternative Medicine, vol. 2013, Article ID 810632, 16 pages, 2013. 
[49] S. A. Sakr and S. Y. Shalaby, "Metiram-induced histological and histochemical alterations in Liver and kidney of pregnant mice," Life Science, vol. 9, no. 1, 2012.

[50] S. Y. Park, H. W. Shin, K. B. Lee, M.-J. Lee, and J.-J. Jang, "Differential expression of matrix metalloproteinases and tissue inhibitors of metalloproteinases in thioacetamide-induced chronic liver injury," Journal of Korean Medical Science, vol. 25, no. 4, pp. 570-576, 2010.

[51] D. Abraham, M. Ponticos, and H. Nagase, "Connective tissue remodelling: cross-talk between endothelins and matrix metalloproteinases," Current Vascular Pharmacology, vol. 3, no. 4, pp. 369-379, 2005.

[52] Y. Wang, J.-S. Zhang, G.-C. Huang, Q. Cheng, and Z.-H. Zhao, "Effects of adrenomedullin gene overexpression on biological behavior of hepatic stellate cells," World Journal of Gastroenterology, vol. 11, no. 23, pp. 3549-3553, 2005.

[53] J. H. An, J. Seong, H. Oh, W. Kim, K. H. Han, and Y. H. Paik, "Protein expression profiles in a rat cirrhotic model induced by thioacetamide," The Korean Journal of Hepatology, vol. 12, no. 1, pp. 93-102, 2006.

[54] M. J. P. Arthur, "Fibrogenesis II. Metalloproteinases and their inhibitors in liver fibrosis," The American Journal of Physiology, vol. 279, no. 2, pp. G245-G249, 2000.

[55] H. K. Kim, T.-H. Yang, and H.-Y. Cho, "Antifibrotic effects of green tea on in vitro and in vivo models of liver fibrosis," World Journal of Gastroenterology, vol. 15, no. 41, pp. 5200-5205, 2009. 